\title{
Build Critical Thinking Skills of Elementary School Students Through Comics social Science Based-Problem
}

\author{
F W Ariesta ${ }^{1}$, E Purwanti $^{2}$ \\ ${ }^{1}$ Faculty of Humanities, Universitas Bina Nusantara, Jakarta, Indonesia \\ ${ }^{2}$ Faculty of Education, Universitas Negeri Semarang, Semarang, Indonesia \\ ${ }^{1}$ freddy.ariesta@binus.ac.id
}

\begin{abstract}
This study aims to build the critical thinking skills of learners in Elementary School and describes the Social Science enhancement of critical capabilities in terms of motivation to learn. Research activities were conducted experimentally for 4 weeks to determine the impact of Comic Based-Problem interventions used in teaching Social Science in building critical thinking skills in learners. The sample of this study is the fourth grades students of Petompon 01 Semarang Elementary School as the experimental class $(n=38)$. This research method using quasi experimental design with pretest posttest. The research instrument was taken from the data of the observation sheet, questionnaire and n-gain test then analyzed using qualitative descriptive percentages. The results showed that there was an increase in critical thinking skills through the Comic Social Science Based-Problem. Motivation learning has a very strong relationship with critical thinking. Students with high learning motivation have high critical thinking skills. Learners with moderate learning motivation have moderate critical thinking skills. Learners with low learning motivation have low critical thinking skills.
\end{abstract}

Keywords: Critical Thinking Skills, Learning Motivation, Elementary School

\section{INTRODUCTION}

Social Science learning materials in elementary school terms with the concept, definition and principles of abstract, need serious attention for the purpose of learning more meaningful. Meaningfulness of learning objectives, it will be better and more effective when teaching materials, learning media and given tasks that felt familiar, intimate, and touching self-learners. Meaningfulness of learning can be achieved when there is a substantive relationship aspects of concepts, information or new situations with the relevant components contained in the structure of the self-learners [1]. Both in relationships that are derivative, corrective, and supportive relationships that are qualitative. Meaningful learning is indeed the first step to achieving quality learning outcomes [2]. Social Science Education of the 21st century is oriented towards developing strategies and solutions to solve problems in everyday life. Teachers should consider the importance of using a variety of collaborative approaches and participatory pedagogy in the learning process. Learning needs, learning media and different learning methods, which make students able to understand the Social Science at a high level 
for example, investigating and solving problems related to the environment where they live [3]. Students are expected to develop high level thinking skills in preparation to face the challenges of everyday life, through learning activities that encourage the use of high-level thinking skills such as critical thinking, reasoning and reflective [4]

The purpose of Social Science subjects at the level of Basic Education is to have the basic ability to think logically and critically, curiosity, inquiry, problem solving and skills in social life [5]. High-level thinking makes students able to interpret, analyze and provide alternative solutions to problems. One high level thinking skill is critical thinking. Critical thinking is the key competencies required to solve problems necessary for the individual to live a successful and responsible life and for the community to meet the challenges of the present and the future. Critical thinking is important to develop because it can improve the quality of thinking for an individual to skillfully analyze, assess, and reconstruct what he thinks to solve problems. Critical thinking skills related to learning motivation of a person [6].

Motivation learning is the overall effort in the learners that leads to learning activities, which ensures the continuity of the learning activities and gives the direction of learning activities, so that the desired activities are achieved [7]. Students who are highly motivated to learn enable high learning outcomes, meaning that the higher the motivation, the more intensity of effort and effort, the higher critical thinking skills.

Based on the findings Kartono, ST. On the low critical thinking in learning Social Science in Elementary School caused by several things: (1) the low culture of reading for students in elementary school, (2) the interest of students towards subjects of Social Science is low because the learning materials are too numerous and widespread , (3) Social Science material is less attractive because students think the benefits are not real and tend to be abstract, (4) teachers are less creative in presenting and teaching Social Science learning materials, (5) environmental conditions and learning media that are less supportive [8]. The ability of Indonesian students to work on questions with reasoned domains also shows that their abilities are still very minimal [8].

Referring to the findings, the implementation of Social Science lesson in Elementary School implicitly becomes a challenge for an educational practitioner, especially teachers need to develop effective learning innovation so as to accelerate the process of achieving educational goals, such as the use of teaching materials and learning media that can stimulate learners to think critically through high learning motivation. Phase of child development according to Piaget, students in elementary school class IV is in concrete operational stage (age 7 to 11 years) [9]. Children at this stage have difficulty with abstract thinking, practical mindedness and can solve grounded problems based on understandable reality [10]. This requires an approach that can be done by applying various strategies in it. One of them is by using Social Science comic media which contains material content about problem based learning or problem solving tailored to stage of cognitive development of learners. The teacher does not provide a direct solution to the problem given, the teacher's task is to direct students to help the thinking process and analysis [11].

Implementation of Social Science learning by using comic learning based on ProblemBased media can connect learning materials with information in the real environment through the problems raised in the comic, so that learners can construct their own knowledge through their learning experiences in developing critical thinking skills and problem solving. Problem Based Learning has the potential to help learners how to learn, how to work together and apply what they learn to understand and solve real-world problems [12]. Critical thinking and engagement of learners is the ability to solve problems, and provide the philosophical principles to support PBL [13]. 
The purpose of this study is to analyze the increase in critical thinking skills and describe Social Science on improving critical thinking skills in terms of the motivation of learners after the implementation of instructional comics media based problem on the learning of Social Science in Elementary Schools.

\section{LITERATURE REVIEW}

\subsection{Comics MediaBased-Problem}

Comics serve to entertain the readers [14]. The main role of comic books in instructional is their ability to create students' interests [15].

In this study, in addition to entertaining comic function is used as a medium of learning so that students are motivated to improve their learning outcomes. Comic learning media can be divided into two, namely comic strip and comic book [16]. Comic strips are shaped sheets of frame columns are usually serialized story. While that is a comic is a comic book in the form of a book, have a longer story, can be directly finished or could be continued.

Reading comics can train the sensitivity of learners 'feelings and views to everyday life, comics also have a role in triggering reading interest and learners' motivation [17]. In this study, which is used in the form of instructional media comic book stories, simple to facilitate learners to understand the concrete problems in society which included the contextual material in the neighborhood.

\subsection{Social Science}

The definition of Social Science is the simplification or adaptation of the disciplines of the social sciences and humanities, as well as basic human activities that are organized and presented scientifically and pedagogically for educational purposes [18], [19].

Social Science at the school level aims to prepare students Have the basic ability to think logically and critically, curiosity, inquiry, problem solving and skills in social life [18]. Therefore, through Social Science learners can learn to understand social problems and decision-making abilities and participate in various community activities to become good citizens.

\subsection{Critical Thinking Skills}

Critical thinking is reflective thinking in depth in decision making and problem solving to analyze situations, evaluate arguments, and draw appropriate conclusions [20]. Someone capable of think critically are capable of being deduced what he knows, know how to use information to solve the problem, and the ability to find the source of relevant information to support problem solving [20].

Critical thinking is the key competencies required to solve problems necessary for the individual to live a successful and responsible life and for the community to meet the challenges of the present and the future. Critical thinking is important to develop because it can improve the quality of thinking for an individual to skillfully analyze, assess, and reconstruct what he thinks to solve problems [6].

The ability to think critically is related to the learning motivation possessed by someone. Motivation learning is the overall driving force in the learners that leads to learning activities, 
which ensures the continuity of the learning activities and gives the direction of learning activities, so that the desired activity is achieved [6]. Learners who are motivated to learn high allows to obtain high learning results as well, meaning that the higher the motivation, the more intensity of effort and efforts made, the higher critical thinking skills.

\section{METHODS}

\subsection{Design}

The study was conducted in quasi-experimental design with one group pretest posttest study [21]. Learners are given pretest before treatment and posttest after treatment [22]. Data critical thinking skills in the classroom control and experiment were analyzed using descriptive analysis of the percentage.

\subsection{Subject}

Subject test is 38 learners of Elementary School fourth grade are divided into several study groups with each consisting of 4-5 members.

\subsection{Data Collection Instruments}

Researchers develop observation sheet to assess the critical thinking skills of learners that arise during the course to observe the observer. then using a questionnaire to obtain data on the motivation of learners. Researchers are also developing an evaluation test sheet in the form of multiple choice questions and worksheets learners to measure academic achievement.

\subsection{Data Analysis}

Researchers organized, coded, reviewed and analyzed sheets of observation of critical thinking skills, data were analyzed with descriptive percentages. Researchers also used the ngain test to analyze academic achievement [22]. In addition, researchers also obtained data from questionnaires learners do after the trial is completed, the data is to know about the motivation of learners were analyzed with descriptive percentage to get more information.

\section{RESULTS AND DISCUSSION}

Final data obtained in this study is the data value learners fourth grade 01 Petompon, Semarang is data value of pretest and posttest value data critical thinking skills after being given treatment using Comics Based-Problem in Social Science subjects. Based on the research result, the average of pretest and posttest value of experimental class learners are 47,66 and 70,6. Comic Media Social Science Based-Problem has an opportunity to empower critical thinking skills that can ultimately improve learners' learning outcomes. Problem-Based Learning is a powerful pedagogical approach to teaching critical thinking skills [23].

The calculation of the gain value obtained results with high criteria of 8 students, moderate criteria of 26 students, and low criteria of 4 students. The improvement of students' critical thinking ability is $89.53 \%$ consisting of learners who have medium and high gain normality 
values. The average increase in gain normality value $(\mathrm{g})$ of 38 students was 0.47 with moderate criteria. The results of the classification of learners based on the achievement of research results of critical thinking and learning motivation with high, medium and low criteria can be seen in table 1 and 2 .

Table 1. Levels of Critical Thinking Skill

\begin{tabular}{ccc}
\hline Score & Category & Students \\
\hline $67 \leq \mathrm{x} \leq 100$ & High & 26 \\
$34 \leq \mathrm{x}<67$ & Medium & 9 \\
$0 \leq \mathrm{x}<34$ & Low & 3 \\
\hline
\end{tabular}

Table 2. Levels of Motivation

\begin{tabular}{ccc}
\hline Score & Category & Students \\
\hline $85 \leq \mathrm{x} \leq 112$ & High & 11 \\
$57 \leq \mathrm{x}<85$ & Medium & 23 \\
$28 \leq \mathrm{x}<57$ & Low & 4 \\
\hline
\end{tabular}

The value of ' $r$ ' between critical thinking and learning motivation of the experimental class students is a correlation of 0.971 including the very strong correlation category. The coefficient of determination is seen from the $r$ square value of 0.943 . This means that $94.3 \%$ of critical thinking students have is able to be explained by the high and low motivation to learn, while the remaining $5.7 \%$ may be caused by other factors.

Learners who have high motivation tend to have high critical thinking skills as well. Motivation has a strong relationship with critical thinking skills [20]. Students with high learning motivation and high critical thinking skills have an interest in problem solving, liking challenges, and having demands or attention from parents at home about the learning outcomes achieved. Students with high critical thinking skills consistently able to analyze problems and develop thinking so that it can be classified in thinking about and excel. Think about (advanced thinking) is active thinkers analyze the mind, have important knowledge about the problem at the level of deep thinking, but they have not been able to think on a higher level consistently across all dimensions of life [6]. Thinking (accomplished thinking) is a thinker internalizes the basic ability of thinking in depth, critical thinking is done consciously and high.

\section{CONCLUSION}

Based on the results of research and discussion that has been done got the following conclusions: (1) critical thinking skills of students in grade IV of elementary school increased after learning to apply comic media Social Science Based-Problem, (2) learning motivation has a very strong relationship with the ability to think critical. Motivation to learn affects the ability to think critically $94.5 \%$, while the remaining $5.5 \%$ is caused by other factors. Students with high learning motivation has a high critical-thinking skills. Students with moderate learning motivation are having moderate critical-thinking skills. Students with low learning motivation have low critical-thinking skills. 


\section{REFERENCES}

[1] R. W. Dahar, Teori-teori Belajar. Jakarta: Erlangga, 1996.

[2] B. Y. Nurhadi and A. G. Senduk, Pembelajaran Kontekstual dan Penerapannya Dalam KBK. Malang: UM Press, 2004.

[3] D. A. McFarlane, "Understanding the Challenges of Science Education in the $21^{\text {st }}$ Century: New Opportunities for Scientific Literacy," Int. Lett. Soc. Humanist. Sci., vol. 4, pp. 35-44, Sep. 2013.

[4] G. M. Saido, S. Siraj, A. B. B. Nordin, and O. S. Al-Amedy, "Higher Order Thinking Skills Among Secondary School Students in Science Learning The Malaysian," J. Educ. Sci., vol. 3, no. 3, pp. 13-20, 2015.

[5] Depdiknas, Permendiknas No 22 Tahun 2006 Tentang Standar Isi. Jakarta: Departemen Pendidikan Nasional, 2006.

[6] M. Scriven and R. Paul, "Defining Critical Thinking," in The 8th Annual International Conference on Critical Thinking and Education Reform, 2013.

[7] A. Sardiman, Interaksi dan Motivasi Belajar Mengajar. Jakarta: Rajawali Press, 2011.

[8] Kemendikbud, Materi Pelatihan Implementasi Kurikulum 2013. Jakarta: kementerian Pendidikan dan Kebudayaan, 2015.

[9] J. Piaget and B. Inhelder, Psikologi Anak. Yogyakarta: Pustaka Pelajar, 2010.

[10] R. E. Slavin, Cooperative Learning: Teori, Riset dan Praktik. Bandung: Nusa Media, 2005.

[11] S. J. Park and S. Choi, "Effects of Problem-based Learning on the Learning Attitudes, Critical Thinking Disposition and Problem-Solving Skills of Nursing Students," Infant Care Adv. Sci. Tech., vol. 103, pp. 192-196, 2015.

[12] C. E. Hmelo-Silver, "Problem-Based Learning: What and How Do Students Learn?," Educ. Psychol. Rev., vol. 16, no. 3, pp. 235-266, Sep. 2004.

[13] A. Armitage, "Conscientization, dialogue and collaborative problem based learning," J. Probl. Based Learn. High. Educ., vol. 1, no. 1, pp. 1-18, 2013.

[14] N. Sudjana and A. Rivai, Media Pengajaran. Bandung: Sinar Baru Algensindo, 2010.

[15] A. Rohani, Media intruksional Edukatif. Jakarta: PT Rineka Cipta, 1997.

[16] Trimo, Media Pendidikan. Jakarta: Depdikbud, 1997.

[17] S. Botzakis, "Adult Fans of Comic Books: What They Get Out of Reading," J. Adolesc. Adult Lit., vol. 53, no. 1, pp. 50-59, Sep. 2009.

[18] W. Parker, Social Studies in Elementary Education. New York: Pearson, 2012.

[19] L. S. Levstik, Handbook of Research in Social Studies Education. UK: UK Taylor\&Francis Group, 2008.

[20] R. Stobaugh, Assessing Critical Thinking in Middle and High Schools. New York: Routledge, 2013.

[21] L. Cohen, L. Manion, and K. Morrison, "Action research," in Research Methods in Education, New York and London: Routledge, 2002.

[22] N. S. Sukmadinata, Metode Penelitian Pendidikan. Bandung: Rosdakarya, 2005.

[23] M. Y. C. . Kek and H. Huijser, "The Power of Problem-Based Learning in Developing Critical Thinking Skills: Preparing Students for Tomorrow Digital Futures in Today's Classrooms," J. High. Educ. Res. Dev., vol. 30, no. 3, pp. 329-341, 2011. 